\title{
Screening of Norwegian lobsters Homarus gammarus for the lobster pathogen Aerococcus viridans
}

\author{
Ragnhild Wiik $^{1}$, Emmy Egidius ${ }^{1}$, Jostein Goksøyr ${ }^{2}$ \\ ${ }^{1}$ Institute of Marine Research, Directorate of Fisheries, PO Box 2906, N-5011 Bergen-Nordnes, Norway \\ ${ }^{2}$ Department of Microbiology and Plant Physiology, University of Bergen, N-5014 Bergen-University, Norway
}

\begin{abstract}
Hemolymph samples drawn from 3044 lobsters trapped along the southwestern part of the Norwegian coast in the period 1981 to 1984 were individually examined for Aerococcus viridans, the causative agent of gaffkemia. In 1981, one of 779 hemolymph samples was positive with respect to the bacterium. During the period 1982 to 1984,2265 lobsters were examined and found negative for A. viridans. These results, together with the fact that gaffkemia has not been reported in the region since 1980, suggest that the disease is not enzootic in these waters. Because of the high survival capacity of the lobster pathogen, strong measures with respect to disinfection of ponds and tanks are recommended following outbreaks of gaffkemia.
\end{abstract}

\section{INTRODUCTION}

Gaffkemia is an infection of lobsters caused by the bacterium Aerococcus viridans (Evans 1974). The disease can cause heavy mortalities among both Homarus americanus $H$. Milne Edwards 1837 and H. gammarus L. held in captivity (Wood 1963, Stewart \& Rabin 1970, Staveland \& Kjos-Hansen 1978), and has been found to occur at variable frequencies among free-living $H$. americanus on the Atlantic Coast of North America (Goggins \& Hurst 1960, Stewart et al. 1969a) and in H. gammarus along the coast of the southern United Kingdom (Wood 1965) and the Atlantic Coast of France (Audoin \& Leglise 1971). A. viridans is probably transmitted to the lobster through integumental defects rather than by consumption of infected food (Stewart et al. 1969 a). A comprehensive review of studies on gaffkemia has been given by Stewart (1980).

Gaffkemia was reported in Norway for the first time in 1976. The likely infection source was Homarus americanus imported from Canada (Håstein et al. 1977. Egidius 1978). During the first week after arrival in Stavanger, about $23 \%$ of the 500 imported lobsters $H$. americanus died. The high mortality rate was blamed on polluted water in the town basin; as a consequence, the remaining lobsters were then moved to a pond at
Kvitsøy, an island situated about $25 \mathrm{~km}$ northwest of Stavanger. Mortalities among the imported lobsters, however, continued, and gaffkemia was diagnosed as the cause (Håstein et al. 1977).

New outbreaks of gaffkemia occurred in Stavanger and at Kvitsøy in 1977 and 1980; all 6 ponds in the area suffered from the disease. The following facts provide a relevant background: (1) between 1976 and 1980, only Scottish Homarus gammarus was imported to Norway; (2) gaffkemia has never been reported in lobster ponds in Scotland; and (3) moreover, in 1980, the disease occurred in a lobster pond containing local lobsters only.

Free-living local lobsters may have included carriers of pathogenic strains of Aerococcus viridans generated by the dumping of gaffkemic lobsters in the sea during the previous outbreaks. It has been shown also that A. viridans survives in marine sediments (Kellog et al. 1974) and in tanks after removing infected lobsters (Schapiro et al. 1974).

Accordingly, in light of the foregoing, a study was undertaken to determine whether the local lobster population included individuals infected with Aerococcus viridans, and the survival of $A$. viridans in sediments was tested experimentally to determine the necessity for disinfection of a lobster pond where gaffkemia had occurred. 


\section{MATERIALS AND METHODS}

Lobsters Homarus gammarus were caught in pots along the coast of the Rogaland region in autumn, and transferred to 2 commercial locations (Fig. 1). Here they were kept for a period varying from 1 wk to $3 \mathrm{mo}$. In most cases, hemolymph samples were taken just before the lobsters were packed for export. Each lobster weighed approximately $0.5 \mathrm{~kg}$.

Location 1 is a lobster pond at Kvitsøy, an island situated about $25 \mathrm{~km}$ northwest of Stavanger (Fig. 1). Prior to bacteriological examination, the lobsters were transferred to indoor, shallow tanks supplemented with fresh flowing seawater. The 297 lobsters which were tested $1 \mathrm{wk}$ after being trapped were transferred directly to the indoor tanks, and brought to the lobster pond after being tested.

Location 2, in Stavanger, consisted of indoor, shallow glass-fiber tanks with fresh flowing seawater.

Bacterial sampling. Aerococcus viridans was isolated from both hemolymph and pond sediments according to the method of Stewart et al. (1966) with some modifications. A hemolymph sample of $0.5 \mathrm{ml}$ was drawn from the ventral abdominal sinus of each lobster and transferred to a tube containing selective enrichment isolation medium (SEIM). The tubes were kept at about $15^{\circ} \mathrm{C}$ for a maximum of $24 \mathrm{~h}$ before reaching the laboratory. There they were incubated at $30^{\circ} \mathrm{C}$, which was the general incubation temperature chosen in this work because it reduced the number of interfering cold-adapted marine bacteria. Hemolymph smears for gram-staining were made directly from $5 \%$ of the lobsters, randomly selected.

Tubes with culture medium changing in color from purple to yellow after 1 to $3 \mathrm{~d}$ at $30^{\circ} \mathrm{C}$ were declared positive in the presumptive test. The SEIM-agar plates (SEIM supplemented with $1.5 \%$ agar) were streaked from the presumptive positive medium. Changing the agar-substrate from Phenyl Ethyl Alcohol-agar (PEA) (Stewart et al. 1966) to SEIM-agar made it possible to exclude many bacterial strains at this early stage, based on degree of acid-production, in addition to colony morphology, catalase-production, and gram-stain reaction. The SEIM-agar plates were examined after $48 \mathrm{~h}_{\text {i }}$ Aerococcus viridans on SEIM-agar forms small, whitish colonies with entire, partly transparent edges, and surrounded by a barely visible yellow zone. Such colonies composed of catalase-negative, gram-positive cocci occurring in tetrads, or larger groups composed of tetrads, were streaked on nutrient agar (Oxoid Ltd., London, England) with $5 \%$ defibrinated sheep blood (blood agar) for determination of hemolytic ability.

Sediments. Samples of 300 to $500 \mathrm{~g}$ sediment/water were collected in sterile containers at each of 19 sites distributed within 3 of the lobster ponds at Kvitsøy which were affected by gaffkemia in 1980/81. The ponds had not yet been disinfected after the last outbreak; when sampling was done in May 1981, the

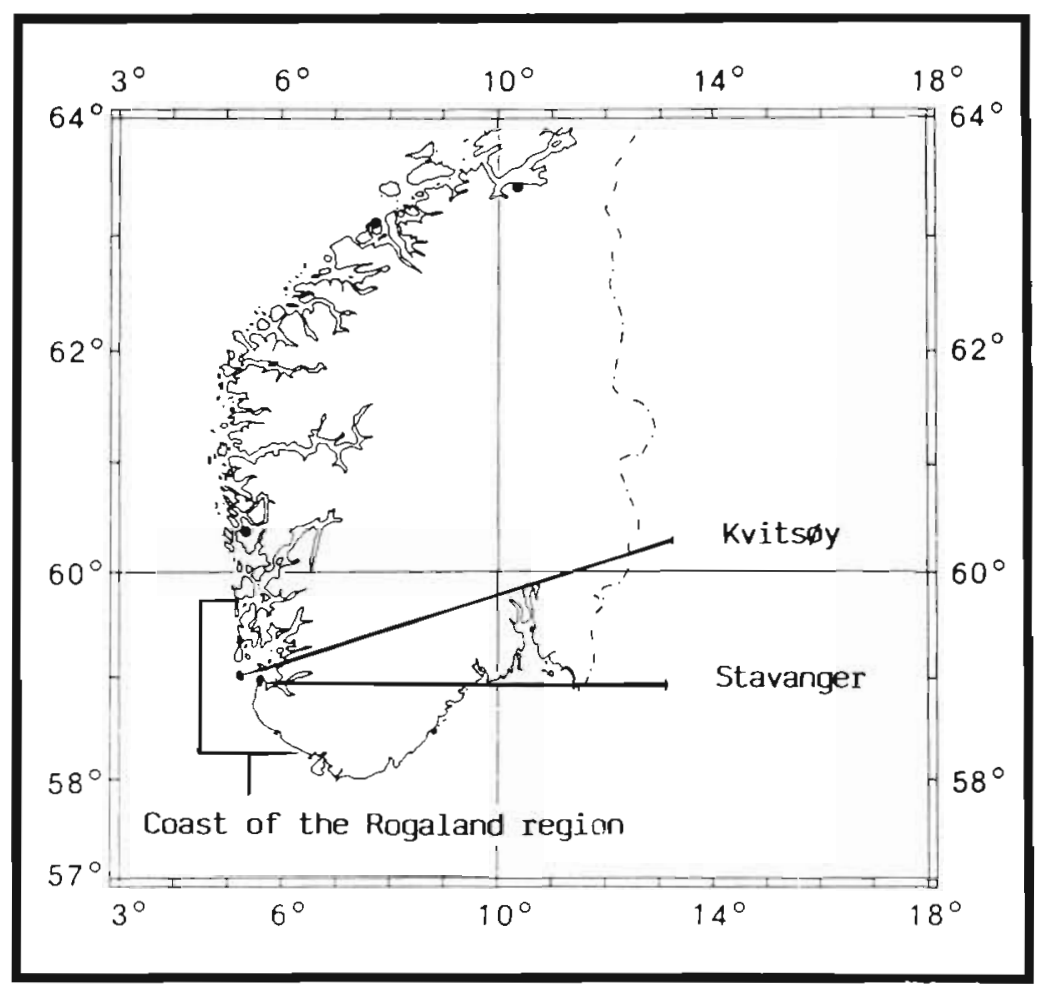

Fig. 1. Location of Stavanger, Kvitsøy, and the coast of the Rogaland region, Norway 
ponds had not been stocked for 4 mo. The samples were kept at 5 to $10^{\circ} \mathrm{C}$ for processing the next day. Each sample was then mixed well, and 50 to $100 \mathrm{~g}$ was transferred to a flask containing $200 \mathrm{ml}$ of SEIM, which was incubated aerobically with continuous shaking. Further treatment was carried out as described for the hemolymph samples.

Experimental testing of survival of Aerococcus viridans in sediments. The $A$. viridans strain used was isolated from an infected lobster about 8 mo prior to the survival experiment and was kept on blood agar. Five $\mathrm{ml}$ of a $48 \mathrm{~h}$ SEIM-culture was inoculated into each of 2 Petri dishes with approximately $50 \mathrm{~g}$ of sterile, marine sediments. The dishes were incubated at $5^{\circ} \mathrm{C}$ for 20 mo. The material was tested monthly according to the selective enrichment isolation method.

\section{RESULTS}

Of the more than 3000 Norwegian lobsters Homarus gammarus examined for the presence of the pathogen Aerococcus viridans in the period 1981 to 1984 (Table 1), only one hemolymph sample exhibited the bacterium. The infected lobster was 1 of the 579 individuals examined at Location 2 in December 1981. One strain of $A$. viridans was isolated from sediments of a lobster pond at Kvitsøy about 4 mo after the infected lobsters (Table 2) had been removed.

Virulence testing of several Aerococcus viridans strains showed that the 2 strains fulfilling all the presumptive and confirmative criteria (Tables 1 \& 2) were virulent to lobsters (Wiik et al. 1986). A. viridans survived for 19 mo in sediments kept in a Petri dish at $5^{\circ} \mathrm{C}$. The strain used (HI 510) was still virulent after $19 \mathrm{mo}$; after 20 mo, bacteria could not be isolated from this substrate.

\section{DISCUSSION}

In examining more than 3000 Norwegian lobsters for the pathogen Aerococcus viridans, only one hemolymph sample was found to be positive. The infected lobster was one of 579 specimens tested at an indoor holding unit (Location 2) in December 1981. This extremely low prevalence may seem incompatible with the epizootic nature of gaffkemia, but it could be explained by the low water temperatures $\left(4\right.$ to $5^{\circ} \mathrm{C}$ ) during the actual period, which would have slowed development and onward transmission (Stewart et al. 1969 b).

The glass-fiber tanks in Location 2 had been thoroughly disinfected before the lobster intake in 1981, and it therefore seems reasonable that the infec-

Table 1. Aerococcus viridans. Prevalence among lobsters from the coast of the Rogaland region

\begin{tabular}{|c|c|c|c|c|c|}
\hline Sampling month & Water temp. $\left({ }^{\circ} \mathrm{C}\right)$ & Pond location & $\begin{array}{c}\text { Number of } \\
\text { lobsters sampled }\end{array}$ & $\begin{array}{l}\text { Presumptive } \\
\text { positive }\end{array}$ & $\begin{array}{l}\text { Confirmed } \\
\text { positive }\end{array}$ \\
\hline December 1981 & 4.7 & Location $1^{\circ}$ & 200 & 57 & 0 \\
\hline December 1981 & 4.6 & Location $2 \cdots$ & 579 & 225 & 1 \\
\hline December 1982 & 7.0 & Location 1 & 697 & 25 & 0 \\
\hline June 1983 & 9.0 & Location 1 & 297 & 6 & 0 \\
\hline December 1983 & - & Location 1 & 395 & 11 & 0 \\
\hline October 1984 & - & Location 1 & 876 & 21 & 0 \\
\hline Total & & & 3044 & 345 & 1 \\
\hline $\begin{array}{l}\text { - Situated at Kvitsøy } \\
\cdots \text { Situated in Stavanger }\end{array}$ & & & & & \\
\hline
\end{tabular}

Table 2. Aerococcus viridans. Prevalence in bottom sediments of lobster ponds at Kvitsøy

\begin{tabular}{|lrrc|}
\hline Lobster pond & Samples & $\begin{array}{c}\text { Presumptive Confirmed } \\
\text { positive }\end{array}$ & positive \\
\hline Location 1 & 14 & 14 & 0 \\
Pond $2^{\circ}$ & 4 & 4 & 1 \\
Pond $3^{\circ}$ & 1 & 1 & 0 \\
Total & 19 & 19 & 1 \\
- Ponds 2 and 3 were not used after the outbreaks of \\
gaffkemia in 1980
\end{tabular}

tion source came from outside the holding unit. The lobsters had been stored for several weeks in Location 2 before being tested, and because gaffkemia is comparatively easily transferred at high lobster densities, the frequency measured among the captive lobsters should be higher than among feral lobsters. An argument pointing in the opposite direction is that lobsters infected with Aerococcus viridans lose interest in food (bait) soon after infection (Stewart et al. 1972), implying that gaffkemic lobsters would not be fully represented in lobster catches. Thus an accurate infection frequency among free-living lobsters could not be deter- 
mined, but it must be estimated as being very low in 1981. During the period 1982 to 1984,2265 lobsters were examined and found to be negative with respect to $A$. viridans. This result, together with the very low prevalence in 1981, and outbreaks of gaffkemia being restricted to the period 1976 to 1980 in the Stavanger area, suggest that the disease is not enzootic in these waters.

The modified selective enrichment isolation method turned out to be effective and reliable with respect to detecting Aerococcus viridans.

According to infection experiments, the only strain of Aerococcus viridans isolated from the lobsters was virulent to Homarus gammarus (Wiik et al. 1986); mean time to death was in agreement with the results of Stewart et al. (1969b). According to Deibel \& Niven (1960), A. viridans does not consistently form tetrads when grown in or on media which yield reduced growth. In our experience, a prominent phenotypic characteristic of the pathogenic $A$, viridans is its very stable tetrad-forming capacity under all growth conditions described in the present paper. The stability of tetrad-forming has been confirmed by ultrasonic treatment (Wiik et al. 1986). We therefore accepted tetrads occurring singly or in clusters of 2 to about 20 tetrads as the only constellation indicative of cocci pathogenic to lobsters.

The strain of Aerococcus viridans isolated from sediments of a lobster pond 4 mo after removing the infected lobsters was still virulent (Wiik et al. 1986). This result, as well as that from the survival experiment, indicates that it is clearly necessary to disinfect following outbreaks of gaffkemia to avoid further episodes.

Acknowledgements. We thank Hummereksportorenes Noteringsutvalg and J. L. Tiedemanns Tobaksfabrik for financial support, Kjell Meling and Chr. Bjelland \& Co. for providing the lobsters for hemolymph sampling, and $K$. Andersen, H. M. Ellingsen, B. Hjeltnes, R. Lerøy and H. Næss for technical assistance.

\section{LITERATURE CITED}

Audouin, J., Leglise, M. (1971). Note préliminaire sur la présence de Gaffkya homari dans le sang des homards stockés dans les viviers de la région de Roscott. Int. Counc. Explor. Sea, Shellfish Comm. K:26, p. 1-6 (mimeo)

Deibel, R. H., Niven, C. F., Jr. (1960). Comparative study of Gaffkya homari, Aerococcus viridans, tetrad forming cocci from meat-curing brines, and the genus Pediococcus. J. Bacteriol. 79: 175-180.

Evans, J. B. (1974). Genus IV. Aerococcus Williams, Hirch and Cowan 1953, 475. In: Buchanan, R. E., Gibbons, N. E. (ed.) Bergey's manual of determinative bacteriology, 8 th edn. Williams \& Wilkins Co., Baltimore, p. 515-516

Egidius, E. (1978). Lobster import: two outbreaks of gaffkemia in Norway. Int. Counc. Explor. Sea, Shellfish Comm. K:17, p. 1-5 (mimeo)

Goggins, P. L., Hurst, J. W., Jr. (1960). Progress report on lobster gaffkyaremia (red tail). Dept Sea Shore Fish., Maine, p. 1-9 (mimeo)

Håstein, T., Roald, S. O., Kjos-Hansen, B., Staveland, K (1977). Occurrence of gaffkemia in lobsters in Norway. Acta vet. scand. 18: 138-139

Kellog, S., Steenbergen, J. F., Schapiro, H. C. (1974). Isolation of Pediococcus homari, etiological agent of gaffkemia in lobsters, from a California estuary. Aquaculture 3: 409-413

Schapiro, H. C., Mathewson, J. H., Steenbergen, J. F., Kellog, S. Ingram, C., Nierengarten, G., Rabin. H. (1974). Gaffkemia in the California spiny lobster, Panulirus interruptus: infection and immunization. Açuaculture 3: 403-408

Staveland, K., Kjos-Hansen, B. (1978). Gaffkemia på norsk hummer i hummerparker (Gaffkemia among Norwegian lobsters held captive in lobsterponds). Norsk veterinaertidsskrift 90: 101-106

Stewart, J. E. (1980). Diseases. In: Cobb, J. S., Bruce, F. P (ed.) The biology and management of lobsters, Vol. 1. Academic Press, New York, p. 301-342

Stewart, J. E., Rabin, H. (1970). Gaffkemia, a bacterial disease of lobsters (Genus Homarus). In: Snieszko, S. F. (ed.) A Symposium on Diseases of Fishes and Shellfishes. Special Publication No.5. American Fisheries Society, Washington, D. C., p. 431-439

Stewart, J. E., Cornick, J. W. Spears, D. I., McLeese, D. W (1966). Incidence of Gaffkya homari in natural lobster (Homarus americanus) populations of the Atlantic Region of Canada. J. Fish. Res. Bd Can. 23: 1325-1330

Stewart, J. E., Dockrill. A., Cornick, J. W. (1969a). Effectiveness of the integument and gastric fluid as barriers against transmission of Gaffkya homari to the lobster Homarus americanus. J. Fish. Res. Bd Can. 26: 1-14

Stewart, J. E., Cornick, J. W., Zwicker, B. M. (1969b). Influence of temperature on gaffkemia, a bacterial disease of the lobster Homarus americanus. J. Fish. Res. Bd Can. 26: 2503-2510

Stewart, J. E., Zwicker, B. M., Arie, B., Horner, G. W. (1972). Food and starvation as factors affecting the time to death of the lobster Homarus americanus infected with Gaffkya homari. J. Fish. Res. Bd Can. 29: 461-464

Wiik, R., Torsvik, V., Egidius, E. (1986). Phenotypic and genotypic comparisons among strains of the lobster pathogen Aerococcus viridans and other marine Aerococcus viridans-like cocci. Int. J. Syst. Bacteriol. 36: 431-434

Wood, P. C. (1963). Blood disease of lobsters (gaffkemia). Results of investigations made in 1962-63. Int. Counc. Explor Sea, Shellfish Comm. No. 25, p. 1-7 (mimeo)

Wood, P. C. (1965). A preliminary note on gaffkemia investigations in England. Rapp. P.-v. Réun. Cons perm. int. Explor. Mer 156: 303-304 